\title{
The Use of Biologic Agents in the Treatment of Oral Lesions due to Pemphigus and Behçet's Disease: A Systematic Review
}

\section{Gerald E. Davis II',2, George Sarandev', Alexander T. Vaughan', Kamal Al-Eryani ${ }^{3}$, Reyes Enciso ${ }^{4 *}$}

'Advanced graduate, Master of Science Program in Orofacial Pain and Oral Medicine, Herman Ostrow School of Dentistry of USC, Los Angeles, California, USA

${ }^{2}$ Assistant Dean of Academic Affairs, Assistant Professor, Restorative Dentistry, Meharry Medical College, School of Dentistry, Nashville, Tennessee, USA

${ }^{3}$ Assistant Professor of Clinical Dentistry, Division of Periodontology, Dental Hygiene \& Diagnostic Sciences, Herman Ostrow School of Dentistry of USC, Los Angeles, California, USA

${ }^{4}$ Associate Professor (Instructional), Division of Dental Public Health and Pediatric Dentistry, Herman Ostrow School of Dentistry of USC, Los Angeles, California, USA

\section{Article Info}

\section{Article Notes}

Received: : March 11, 2019

Accepted: : April 29, 2020

\section{${ }^{*}$ Correspondence:}

${ }^{*}$ Dr. Reyes Enciso, Associate Professor (Instructional), Division of Dental Public Health and Pediatric Dentistry, Herman Ostrow School of Dentistry of USC, Los Angeles, California, USA; Email: renciso@usc.edu.

${ }^{\circ} 2020$ Enciso R. This article is distributed under the terms of the Creative Commons Attribution 4.0 International License.

\section{Keywords:}

Monoclonal antibodies

Biologic agents

Mucocutaneous lesions

Behçet's disease

Pemphigus

Etanercept

Infliximab

Rituximab

\section{Abstract}

Background: Current treatments for pemphigus and Behçet's disease, such as corticosteroids, have long-term serious adverse effects.

Objective: The objective of this systematic review was to evaluate the efficacy of biologic agents (biopharmaceuticals manufactured via a biological source) on the treatment of intraoral lesions associated with pemphigus and Behçet's disease compared to glucocorticoids or placebo.

Methods: PubMed, Web of Science, Cochrane Library, and EMBASE were searched for randomized controlled studies up to January 2019. Bias was assessed with the risk of bias tool.

Results: Out of 740 references retrieved, only four randomized controlled trials (RCTs) were included, comprised of a total of 158 subjects (138 pemphigus and 20 Behçet's disease). All studies were assessed at high risk of bias. Heterogeneity of data prevented the authors from performing a meta-analysis. Infliximab or rituximab with short-term prednisone showed higher safety and lowered cumulative prednisone dose than prednisone alone in the treatment of pemphigus. Subcutaneous injection of etanercept provided $45 \%$ of patients free of ulcers compared to $5 \%$ in the placebo group in one study with Behçet's disease; however, no difference was found in pemphigus patients.

Conclusion: Though biological agents alone or in combination with prednisone showed favorable results in three RCTs compared to prednisone alone or placebo, a meta-analysis could not be undertaken due to high heterogeneity. Results are inconclusive, and larger, well-designed RCTs are needed.

\section{Introduction}

Pemphigus, Behçet's disease, mucous membrane pemphigoid, oral lichen planus (OLP), and recurrent aphthous ulcers are immunemediated disorders, which commonly have oral manifestations. Though there are variations in the intraoral presentation of these conditions, they often present with ulcerations ${ }^{1}$.

Pemphigus is an autoimmune condition with three major variants: Pemphigus Vulgaris (PV), Pemphigus Foliaceous (PF), and Paraneoplastic Pemphigus (PNP) ${ }^{2}$. Only PV and PNP have common oral involvement ${ }^{3}$. In PV, IgG antibodies targeted against desmoglein-3 (Dsg-3), a protein responsible for cell-cell adhesion, lead to loss of adhesion (acantholysis) and blister formation ${ }^{4}$. In addition to Dsg-3, patients with PNP also have antibodies against Dsg-1 and plakin family ${ }^{3}$. Moreover, PNP is usually associated with underlying malignancy, such as non-Hodgkin lymphoma ${ }^{3}$. 
Although PV and PNP share many clinical findings with other vesiculobullous lesions, it is still very possible to differentiate between them using their unique clinical and histopathological features ${ }^{5}$.

Behçet's disease is an autoimmune disease that targets small blood vessels, causing vasculitis. This leads to clinical effects such as uveitis and oral and genital ulcerations ${ }^{6}$. Currently, there is no cure for Behçet's disease; however, it has been managed using immunosuppressive therapy. The cause of Behçet's disease is unknown, but there are genetic predispositions for the disease, namely, in the Middle East along the path of the original Silk Road ${ }^{7}$. HLA-B51 proteins help aid in the precipitation of Behçet's disease due to chemotaxis hyper-function?

Mucous Membrane Pemphigoid (MMP) is an autoimmune condition that targets hemidesmosomes; lichen planus is a chronic condition with both extraoral and intraoral effects.

Recurrent Aphthous Stomatitis (RAS) are non-specific ulcers of unknown etiology and may be present secondary to systemic diseases ${ }^{8}$. Thalidomide is considered to be an effective therapy to treat RAS, and it can be used in refractory cases with complete remission in 85-90\% of patients ${ }^{9}$.

In addition to palliative therapy such as topical anesthetics, primary therapy for these immune-mediated intraoral lesions consists of glucocorticosteroids, either given topically, as is the case in MMP, Behçet's disease, and OLP or systemically, as in pemphigus for example ${ }^{10-13}$. When lesions in MMP and OLP are recalcitrant to topical glucocorticoids, systemic glucocorticoids are often attempted ${ }^{12}$. However, long-term management with systemic glucocorticoids may present with minor side effects (such as acne) to major (glaucoma, cataract, adrenal atrophy, Cushing's syndrome, increased glucose levels, or cerebral atrophy) outcomes ${ }^{14}$. Although steroids significantly reduced the mortality associated with pemphigus in one retrospective multicenter cohort study, serious side effects are a common cause of morbidity and mortality ${ }^{15}$. It has recently been proposed that treating pemphigus with a combination of rituximab and short-term prednisone is safer and more effective than high doses of corticosteroids ${ }^{16}$. The use of biologic agents has emerged as an additional line of treatment for ineffective immunosuppressive therapy with corticosteroids. Infliximab and rituximab are chimeric monoclonal antibodies, while etanercept is a chimeric fusion protein. Infliximab is a drug that was developed in 1993, and it functions by acting as a TNF- $\alpha$ antagonist ${ }^{17}$. Rituximab conversely targets CD-20 ${ }^{18}$. Etanercept also inhibits TNF- $\alpha^{19}$.

The objective of this systematic review was to evaluate the efficacy of biologic agents (biopharmaceuticals manufactured via a biological source) on the treatment of intraoral lesions associated with pemphigus and Behçet's disease compared to glucocorticoids or placebo.

\section{Materials and Methods}

This systematic review adhered to the Preferred Reporting Items for Systematic Reviews and Meta-analyses (PRISMA) statement ${ }^{20}$ and was registered with PROSPERO \#CRD42019128312.

The PICOS (Patient, Intervention, Comparison, Outcome, Setting) question was:

P: Adult patients with oral lesions associated with pemphigus, MMP, OLP, recurrent aphthous ulcers and Behçet's;

I: Biologic agents alone or in combination with corticosteroid;

C: Placebo or corticosteroid;

O: Reduction in number of oral lesions, number of responders, any quality of life index, duration to the healing of existing blisters, duration to the cessation of new blisters.

S: Hospital/clinic.

\section{Inclusion and exclusion criteria}

Studies were limited to randomized controlled trials comparing the efficacy of biologic agents to placebo or corticosteroids to treat oral lesions associated with pemphigus vulgaris/foliaceus, mucous membrane pemphigoid, Behçet's disease, oral lichen planus, or recurrent aphthous ulcers. Articles not available in English were excluded.

\section{Search methods for identification of studies}

Four electronic databases (MEDLINE via PubMed, EMBASE, Web of Science, and Cochrane Library) were searched on $2 / 27 / 2018$ using the strategies described in Table 1. We re-ran the search for the four databases on $1 / 20 / 2019$, and no relevant results were found.

\section{Data collection and analysis}

Three review authors (G.E.D., G.S., A.T.V.) screened titles and abstracts of the search results for inclusion/exclusion with a fourth author (R.E), making the final decision in case of disagreement. The same three review authors also independently extracted the data from the full-text articles meeting the inclusion criteria. Data extraction included the number of participants and their demographics, inclusion/ exclusion criteria, interventions, and outcome data. The assessment of the risk of bias in the included studies was undertaken independently by the three authors (G.E.D., G.S., A.T.V.) in accordance with the approach described in the Cochrane Handbook ${ }^{21}$. The three assessments are low 
risk, unclear risk, and high risk for each of the following: 1) random sequence generation; 2) allocation concealment; 3) blinding; 4) incomplete outcome; 5) selective reporting; 6) other potential bias.

\section{Statistical analyses}

Meta-analyses could not be conducted due to heterogeneity of the conditions - pemphigus and Behçet's; the biologic interventions - etanercept ${ }^{22,23}$, infliximab ${ }^{24}$ and rituximab $^{16}$; comparison groups - placebo injection ${ }^{22,23}$ or either prednisone alone ${ }^{16}$ or prednisone and placebo ${ }^{24}$; study design - double-blinded $\mathrm{RCT}^{22-24}$ or open-label RCT ${ }^{16}$ and outcomes measured.

\section{Levels of evidence and summary of the review findings}

Quality of evidence assessment and summary of the review findings were conducted following the Cochrane Collaboration and GRADE Working Group recommendations ${ }^{21}$. The GRADE Working Group grades of evidence are:

- High quality: Further research is very unlikely to change our confidence in the estimate of effect

- Moderate quality: Further research is likely to have an important impact on our confidence in the estimate of effect and may change the estimate.

- Low quality: Further research is very likely to have an important impact on our confidence in the estimate of effect and is likely to change the estimate.
- Very low quality: We are very uncertain about the estimate.

\section{Results}

\section{Results of the search}

The initial search strategy through database searching yielded 721 references plus 19 additional records identified through other sources (scanning of the reference section of included studies). 740 records were assessed independently by three review authors (G.E.D., G.D., A.T.V), and based on the abstracts and titles, these were reduced to 27 relevant manuscripts. All 27 manuscripts identified were analyzed for inclusion independently by the same three review authors. Four manuscripts were assessed as relevant for inclusion. The main reasons for exclusion are presented in the PRISMA flowchart (Figure 1). Table 1 provides a summary of the search strategy.

\section{Included Studies}

Although our original search included oral lesions associated with pemphigus vulgaris/foliaceus, MMP, Behçet's disease, oral lichen planus, or recurrent aphthous ulcers, only three RCTs on pemphigus vulgaris/ foliaceus ${ }^{16,22,24}$ and one on Behçet's disease ${ }^{23}$ met inclusion criteria.

Study Design: A single open-label prospective multicenter parallel-group $\mathrm{RCT}^{16}$ and three double-blinded $\mathrm{RCTs}^{22-24}$ were eligible for qualitative analysis (Table 2).

Table 1: Search strategies

\begin{tabular}{|c|c|}
\hline Database & Search strategy \\
\hline $\begin{array}{l}\text { MEDLINE via PubMed } \\
\text { (searched on } 2 / 27 / 2018 \\
\text { and } 1 / 20 / 2019 \text { ) limited } \\
\text { to English language and } \\
\text { Humans }\end{array}$ & $\begin{array}{l}\text { ("Biological Products"(Mesh) OR biological agent* OR monoclonal antibod* OR rituximab OR infliximab OR } \\
\text { tocilizumab OR infliximab OR adalimumab OR etanercept OR golimumab OR certolizumab pegol OR tocilizumab } \\
\text { OR abatacept OR daclizumab OR anakinra) AND (pemphigus OR mucous membrane pemphigoid OR oral lichen } \\
\text { planus OR Behçet* OR recurrent aphthous ulcer* OR aphthous stomatitis) }\end{array}$ \\
\hline $\begin{array}{l}\text { The Web of Science } \\
\text { (searched on } 2 / 27 / 2018 \\
\text { and } 1 / 20 / 2019 \text { ) }\end{array}$ & $\begin{array}{l}\text { (biological agent* OR monoclonal antibod* OR rituximab OR infliximab OR tocilizumab OR infliximab OR adali- } \\
\text { mumab OR etanercept OR golimumab OR certolizumab pegol OR tocilizumab OR abatacept OR daclizumab OR } \\
\text { anakinra) AND (pemphigus OR mucous membrane pemphigoid OR oral lichen planus OR Behçet* OR recurrent } \\
\text { aphthous ulcer* OR aphthous stomatitis) AND random* }\end{array}$ \\
\hline $\begin{array}{l}\text { The Cochrane Library } \\
\text { (searched on } 2 / 27 / 2018 \\
\text { and } 1 / 20 / 2019 \text { ) }\end{array}$ & $\begin{array}{l}\text { \#1. ((biological agent*) OR (monoclonal antibod*) OR rituximab OR infliximab OR tocilizumab OR infliximab OR } \\
\text { adalimumab OR etanercept OR golimumab OR (certolizumab pegol) OR tocilizumab OR abatacept OR daclizum- } \\
\text { ab OR anakinra) } \\
\text { \#2. (pemphigus OR (mucous membrane pemphigoid) OR (oral lichen planus) OR Behçet* OR (recurrent aph- } \\
\text { thous ulcer*) OR (aphthous stomatitis)) } \\
\text { \#3. Randomization OR randomized OR random } \\
\text { \#4. \#1 and \#2 and \#3 }\end{array}$ \\
\hline $\begin{array}{l}\text { EMBASE (searched } \\
\text { on } 2 / 27 / 2018 \text { and } \\
1 / 20 / 2019 \text { ) }\end{array}$ & $\begin{array}{l}\text { \#1.((biological agent*) OR (monoclonal antibod*) OR rituximab OR infliximab OR tocilizumab OR infliximab OR } \\
\text { adalimumab OR etanercept OR golimumab OR (certolizumab pegol) OR tocilizumab OR abatacept OR daclizumab } \\
\text { OR anakinra) } \\
\text { \#2. (pemphigus OR (mucous membrane pemphigoid) OR (oral lichen planus) OR Behçet* OR (recurrent aphthous } \\
\text { ulcer*) OR (aphthous stomatitis)) } \\
\text { \#3. random* } \\
\text { \#4. \#1 and \#2 and \#3 combine }\end{array}$ \\
\hline
\end{tabular}



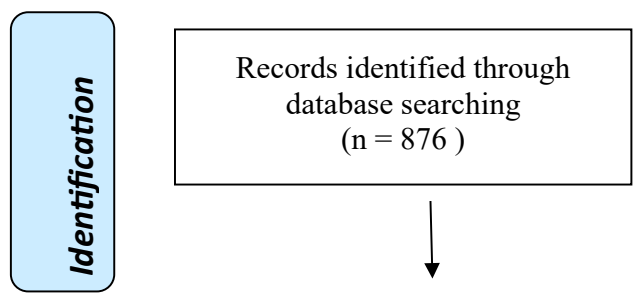
Additional records identified through other sources $(\mathrm{n}=19)$

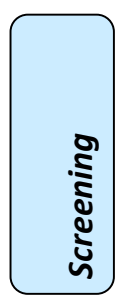

Records after duplicates removed $(\mathrm{n}=740)$

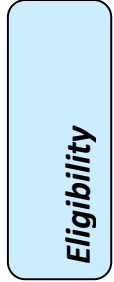

Full-text articles assessed for eligibility $(n=27)$

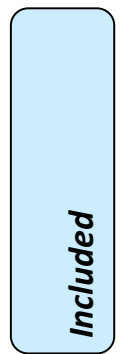

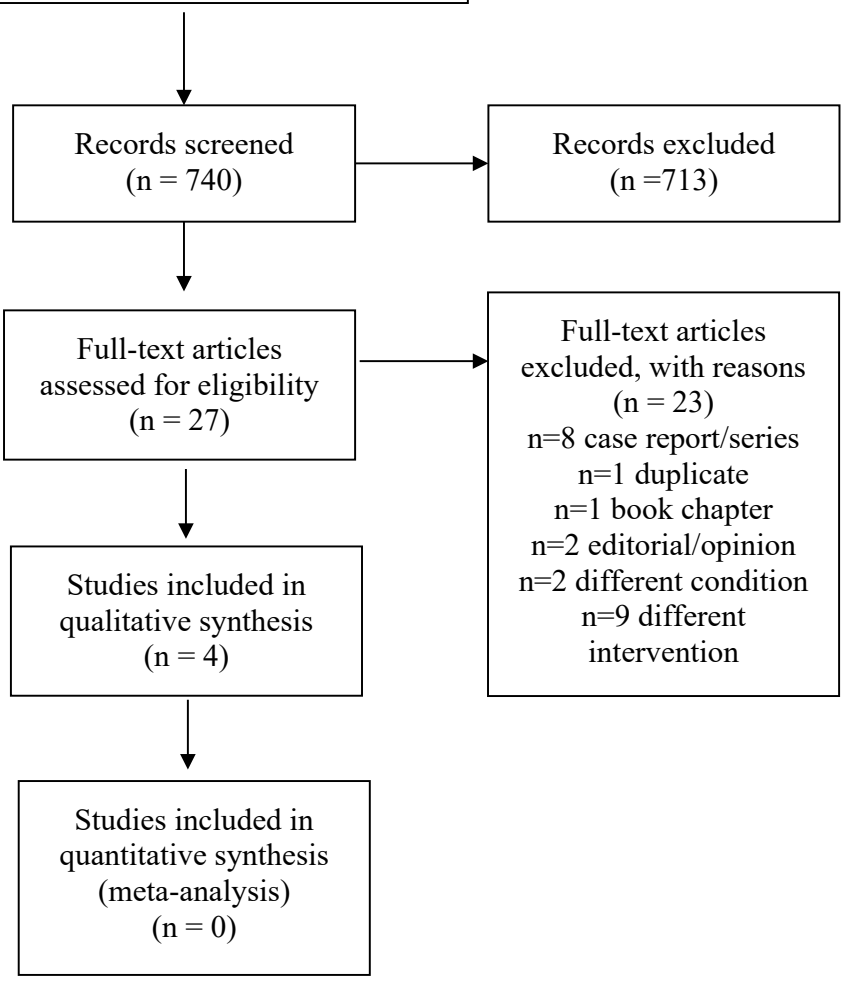

Figure 1: PRISMA flow diagram showing the number of abstracts identified, screened, eligible, and included.

Population:Acombined total of 158adultswereenrolled in these four RCTs (138 pemphigus and 20 Behçet's disease patients). Patients' diagnosis of pemphigus vulgaris/ foliaceus was confirmed via direct immunofluorescence and histology $y^{16,22}$ or via disease activity score ${ }^{24}$. Behçet's disease was confirmed via monosodium urate (MSU) testing and pathergy ${ }^{23}$. All four RCTs included only adults; three of the RCTs enrolled both males and females ${ }^{16,22,24}$, while one, by design, included only male participants ${ }^{23}$. The average age of the participants ranged from 28.5 years $^{23}$ to 54.5 years $^{24}$. The inclusion criteria, as well as the average age and gender distribution of the included studies, are presented in Table 2.

Interventions: Two RCTs randomized participants to receive etanercept $t^{22,23}$, one utilized infliximab ${ }^{24}$, and another utilized rituximab ${ }^{16}$ as their biologic intervention. In two trials ${ }^{16,24}$, the intervention included a corticosteroid, prednisone, along with the biologic medication. In one study ${ }^{16}$, prednisone dosing was based on disease severity (moderate versus severe), while the other study ${ }^{24}$ allowed the investigator to adjust the dose using the best medical judgment. Three RCTs utilized fixed doses of their respective intervention ${ }^{22-24}$, while one ${ }^{16}$ utilized a larger loading dose over two weeks followed by maintenance doses at 12 and 18 months.

Comparison group: Patients in the comparison groups were labeled as controls and received placebo injections ${ }^{22,23}$ or prednisone ${ }^{16}$ or prednisone plus placebo ${ }^{24}$.

Primary outcomes: Melikoglu et $\mathrm{al}^{23}$ reported a primary endpoint of the amount of suppression of the pathergy response (reported as the number of positive responses out of total tested) and MSU test (reported as the area of erythema in $\mathrm{mm}^{2}$ ). In Hall et al. (2015), the primary efficacy endpoint was a response to treatment at week 18. Joly et al. ${ }^{16}$ reported the proportion of patients 
Table 2: Summary of included RCT studies.

\begin{tabular}{|c|c|c|c|c|c|}
\hline Reference & $\begin{array}{l}\text { Country, } \\
\text { Study Type }\end{array}$ & $\begin{array}{c}\text { Intervention groups' } \\
\text { gender }\end{array}$ & $\begin{array}{c}\text { Control groups's } \\
\text { gender }\end{array}$ & Inclusion criteria & $\begin{array}{l}\text { Age, mean } \pm \text { SD } \\
\text { (range) }\end{array}$ \\
\hline \multicolumn{6}{|c|}{ Pemphigus Vulgaris \& Pemphigus Foliaceus } \\
\hline $\begin{array}{l}\text { Fiorentino et } \\
\text { al. (2011) }\end{array}$ & $\begin{array}{l}\text { United } \\
\text { States, } \\
\text { Pilot Study, } \\
\text { DBRCT }\end{array}$ & $\begin{array}{c}\text { 50mg Etanercept } \\
5 \mathrm{M} / 1 \mathrm{~F}\end{array}$ & $\begin{array}{l}\text { Saline } \\
\mathrm{OM} / 2 \mathrm{~F}\end{array}$ & $\begin{array}{l}\text { Diagnosis: Pemphigus Vulgaris } \\
\text { Age: >18; Location(s): Skin } \\
\text { Biopsy Type: Skin } \\
\text { Confirmation: Direct Immunofluorescence \& } \\
\text { Histology }\end{array}$ & $\begin{array}{l}\text { Etanercept: } \\
54.17 \pm 10.26 \\
\text { Saline: } \\
46.5 \pm 11.5\end{array}$ \\
\hline $\begin{array}{l}\text { Hall et al. } \\
(2015)\end{array}$ & $\begin{array}{l}\text { United } \\
\text { States, } \\
\text { DBRCT }\end{array}$ & $\begin{array}{c}\text { Infliximab }(5 \mathrm{mg} / \mathrm{kg})+ \\
\text { Prednisone (dosage } \\
\text { varied) } \\
6 \mathrm{M} / 4 \mathrm{~F}\end{array}$ & $\begin{array}{l}\text { Prednisone }+ \\
\text { placebo } \\
6 \mathrm{M} / 4 \mathrm{~F}\end{array}$ & $\begin{array}{l}\text { Diagnosis: Pemphigus Vulgaris } \\
\text { Age: >18; Location(s): Skin \& Mucosal } \\
\text { Confirmation: Disease activity score, mucosal } \\
\text { and cutaneous, >/= } 2 \\
\text { Timeframe: } 2 \text { Weeks prior to infusion }\end{array}$ & $\begin{array}{l}\text { Infliximab: } \\
52 \text { years } \\
(21-63) \\
\text { Prednisone: } \\
54.5 \text { years }(30-71)\end{array}$ \\
\hline $\begin{array}{l}\text { Joly et al. } \\
\text { (2017) }\end{array}$ & $\begin{array}{l}\text { France, } \\
\text { Open-label } \\
\text { RCT }\end{array}$ & $\begin{array}{l}\text { 500-1,000mg IV Ritux- } \\
\text { imab \& 0.5-1.0 mg/kg } \\
\text { daily prednisone } \\
15 \mathrm{M} / 31 \mathrm{~F}\end{array}$ & 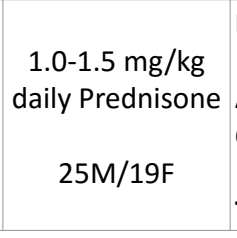 & $\begin{array}{l}\text { Diagnosis: Pemphigus Vulgaris \& Pemphigus } \\
\text { Foliaceus } \\
\text { Age: } 18-80 ; \text { Location(s): N/A } \\
\text { Confirmation: Direct Immunofluorescence \& } \\
\text { Histology } \\
\text { Timeframe: New }\end{array}$ & $\begin{array}{l}\text { Rituximab: } \\
53.5 \text { years } \\
\text { Prednisone: } \\
53.1 \text { year }\end{array}$ \\
\hline \multicolumn{6}{|c|}{ Behçet's Disease } \\
\hline $\begin{array}{l}\text { Melikoglu et } \\
\text { al. (2005) }\end{array}$ & $\begin{array}{l}\text { Turkey, } \\
\text { DBRCT }\end{array}$ & $\begin{array}{c}25 \mathrm{mg} \text { of Etanercept } \\
\text { subcutaneous injec- } \\
\text { tion } \\
20 \mathrm{M} / \mathrm{OF}\end{array}$ & $\begin{array}{l}\text { Placebo } \\
20 \mathrm{M} / 0 \mathrm{~F}\end{array}$ & $\begin{array}{l}\text { Diagnosis: Behçet's Disease } \\
\text { Age: 18-45; Gender: Male } \\
\text { Location(s): Skin (Genital) \& Mucosal (Oral) } \\
\text { Confirmation: Monosodium Urate (MSU) Test } \\
\text { \& Pathergy } \\
\text { Timeframe: Last } 3 \text { Months }\end{array}$ & $\begin{array}{c}\text { Etanercept: } 28.5 \pm 5.3 \\
\text { Placebo: } 30.8 \pm 6.2\end{array}$ \\
\hline
\end{tabular}

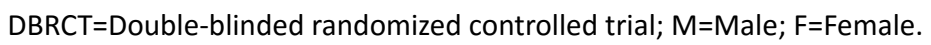

Table 3: Summary of risk of bias for included RCT studies.

\begin{tabular}{|c|c|c|c|c|c|c|c|}
\hline Study & $\begin{array}{c}\text { Random Sequence } \\
\text { Generation }\end{array}$ & Allocation Concealment & Blinding & $\begin{array}{l}\text { Incomplete } \\
\text { Outcome Data }\end{array}$ & \begin{tabular}{|l|} 
Selective \\
Reporting
\end{tabular} & $\begin{array}{c}\text { Other potential } \\
\text { bias }\end{array}$ & Overall Bias \\
\hline Fiorentino et al. (2011) & + & ? & + & + & + & + & + \\
\hline Hall et al. (2015) & - & - & $?$ & + & - & - & + \\
\hline Joly et al. (2017) & - & ? & + & + & - & ? & + \\
\hline Melikoglu et al. (2005) & - & - & + & - & - & + & + \\
\hline
\end{tabular}

Legend: - low risk; + high risk; ? unclear risk

who achieved a complete remission at month 24. Finally, Fiorentino et al. ${ }^{22}$ reported the meantime to achieve a $50 \%$ reduction in the number of active lesions as the primary endpoint.

\section{Risk of bias, outcomes and adverse events}

Overall, all four included studies were considered at a high risk of bias. (Table 3). Table 4 presents the outcomes of the four included RCTs. Table 5 presents the adverse events reported in the four RCTs.

\section{Summary of the evidence and quality of the findings}

The quality of evidence was very low due to the high risk of bias, heterogeneity of the outcomes (only one study reported each outcome of interest), and the small number of studies with a small sample size. Very low evidence grading indicates that we are very uncertain about the estimate of effect.

\section{Discussion}

\section{Summary of the results}

A single open-label prospective multi-center parallelgroup $\mathrm{RCT}^{16}$ and three double-blinded $\mathrm{RCTs}^{22-24}$ were included in this review. A total of 158 subjects in the studies were treated for pemphigus vulgaris/foliaceus (138 patients) ${ }^{16,22,24}$ or Behçet's (20 patients) ${ }^{23}$.

Pemphigus vulgaris/foliaceus: Patients were treated either by IV infliximab plus prednisone ${ }^{24}$, IV rituximab plus prednisone $\mathrm{e}^{16}$, or subcutaneous etanercept ${ }^{22}$. The results were inconclusive when etanercept alone was the active treatment ${ }^{22}$. When infliximab was added to prednisone, a statistically significant improvement was recorded with the Pemphigus Disease Area Index, the Dermatology Quality of Life Index, and Skindex scores; however, this was not the primary endpoint and was evaluated on a perprotocol basis ${ }^{24}$. A complete remission at 24 months, the 
Table 4: Primary outcomes reported in included RCT studies.

\begin{tabular}{|c|c|c|}
\hline Reference & $\begin{array}{c}\text { Interventions and Sample } \\
\text { Size }\end{array}$ & Results \\
\hline \multicolumn{3}{|c|}{ Pemphigus Vulgaris \& Pemphigus Foliaceus } \\
\hline $\begin{array}{l}\text { Fiorentino et } \\
\text { al. (2011) }\end{array}$ & $\begin{array}{l}\text { Group 1: } \\
\text { IV 50mg etanercept }(n=6) \\
\text { Group 2: } \\
\text { Saline }(n=2)\end{array}$ & $\begin{array}{l}\text { The pilot study was halted prematurely after enrollment of } 8 \text { participants. } \\
50 \% \text { reduction in number of lesions was met by } 3 \text { of the } 6 \text { subjects completing the study ( } 2 \text { in } \\
\text { the placebo group, } 1 \text { in the etanercept group). } \\
\text { Total number of lesions decreased more in the placebo group. } \\
\text { DLQI and PGA scores decreased for the treatment and the placebo groups. }\end{array}$ \\
\hline $\begin{array}{l}\text { Hall et al } \\
(2015)\end{array}$ & $\begin{array}{l}\text { Group 1: } \\
\text { IV Prednisone variable } \\
\text { dosage }+ \text { Infliximab }(5 \mathrm{mg} / \\
\mathrm{kg})(\mathrm{n}=10) \\
\text { Group 2: } \\
\text { Prednisone + placebo } \\
(\mathrm{n}=10)\end{array}$ & $\begin{array}{l}\text { None of the primary or secondary efficacy endpoints reached statistical significance. } \\
\text { The primary efficacy endpoint at } 18 \text { weeks was achieved by only one subject in each group. } \\
\text { Three subjects in the treatment group did achieve responder status at week } 26 \text { compared with } \\
\text { no subjects in the placebo group }(P>0.05) \text {. } \\
\text { Subjects treated with infliximab exhibited a decrease in the number of new blisters per week } \\
\text { during the study whereas subjects treated with placebo showed an increase in the number of } \\
\text { new blisters per } \\
\text { week ( } P=0.037 \text { ). } \\
\text { The treatment group achieved better scores in time to cessation of new blisters and healing of } \\
\text { existing blisters, and less days to achieve event. } \\
\text { PDAI score improved more for the treatment group (week } 18 P=.032 \text {, week } 22 p=.008 \text {, week } 26 \\
p=.032 \text { ) } \\
\text { IgG anti-Dsg1 and IgG anti-Dsg3 antibodies decreased significantly for the treatment group at } \\
\text { week } 18 \text { ( } P=0.035) \text {; week } 26 \text { ( } P=0.022 \text { ) } \\
\text { No significant differences in the DLQI scores } \\
\text { Less prednisone was needed to achieve cessation of new blister formation or healing of existing } \\
\text { ulcerations/erosions in the treatment group }\end{array}$ \\
\hline $\begin{array}{l}\text { Joly et al. } \\
\text { (2017) }\end{array}$ & $\begin{array}{l}\text { Group 1: } \\
500-1,000 \mathrm{mg} \text { IV Rituximab } \\
\text { plus short-term } 0.5-1.0 \\
\mathrm{mg} / \mathrm{kg} \text { daily prednisone } \\
(\mathrm{n}=46) \\
\text { Group } 2: \\
\begin{array}{l}1.0-1.5 \mathrm{mg} / \mathrm{kg} \text { daily predni- } \\
\text { sone alone }(\mathrm{n}=44)\end{array}\end{array}$ & $\begin{array}{l}\text { More primary endpoint achievers in the treatment group }(\mathrm{P}<.0001) \\
\text { Complete remission off-therapy achieved at } 24 \text { months close to } 3 \text { times more in the treatment } \\
\text { group ( } 89 \% \text { vs. } 28 \%, P<.0001) \text {. } \\
\text { Median delay to complete remission off-therapy and median duration of complete remission } \\
\text { off-therapy were more than } 1 / 2 \text { lower and } 7 x \text { higher respectively in the treatment group than the } \\
\text { prednisone alone group }(\mathrm{P}<.0001) \text {. } \\
\text { Two-years disease-free survival was twice as high for the rituximab group }(\mathrm{P}=0.0191) \text {. } \\
\text { Cumulative dose for prednisone needed was close to } 1 / 3 \text { lower in the active group }(\mathrm{p}<.0001) \text {. } \\
\text { Total and desmoglein-specific } \mathrm{B} \text {-lymphocytes disappeared in rituximab plus short-term predni- } \\
\text { sone group of patients, and remained unchanged in the prednisone-alone group. } \\
\text { Anti-desmoglein antibodies decreased for the active group and increased after the } 12^{\text {th }} \text { month } \\
\text { for the controls. } \\
\text { Prednisone cumulative dose post treatment was } 3 \times \text { higher in the control group }(\mathrm{P}<.0001) \text {. } \\
\text { At month } 24 \text {, more relapse cases were recorded in the control group. }\end{array}$ \\
\hline \multicolumn{3}{|c|}{ Behçet's Disease } \\
\hline $\begin{array}{l}\text { Melikoglu et } \\
\text { al. (2005) }\end{array}$ & $\begin{array}{l}\text { Group 1: } \\
25 \mathrm{mg} \text { of etanercept subcu- } \\
\text { taneous injection }(\mathrm{n}=20) \\
\text { Group 2: } \\
\text { Placebo }(\mathrm{n}=20)\end{array}$ & $\begin{array}{l}\text { The frequency of pathergy was not different between the two groups at any time. } \\
\text { The area of erythema by MSU was less in the placebo group at Week } 1 \text { and no different than } \\
\text { the etanercept group at Week } 4 \text { and at the third month after the end of the study. MSU was } \\
\text { lower for both study arms at the end of the third month. } \\
\text { The numbers of oral ulcers were less in the treatment group at weeks } 1,2,3 \text { and } 4 \text {. Post-study, } \\
\text { both groups returned to pretreatment levels. } \\
45 \%(9 / 20) \text { of etanercept patients were free of oral ulcers and only } 5 \%(1 / 20) \text { of the control } \\
\text { group }(p=0.0017) \text {. }\end{array}$ \\
\hline
\end{tabular}

DLQI: dermatology life quality index

PGA: Physician global assessment (scale: 0, indicates clear;1, near clear; 2, mild disease; 3, moderate disease; and 4, severe disease) PDAI: Pemphigus Disease Area Index

RR: relative risk

NNT: Number Needed to Treat

Skindex measures the effects of skin diseases on patients' quality of life.

Pathergy positivity: a papule or pustule formation $48 \mathrm{~h}$ after the insertion of a 20 gauge needle

MSU positivity: an area of erythema that formed after subcutaneous injection of $2.5 \mathrm{mg}$ MSU crystals.

median duration of complete remission, and two years of disease-free survival were all higher with IV rituximab plus prednisone compared to prednisone alone control group ${ }^{16}$. Less prednisone was needed to achieve the desired 
Table 5: Adverse events (AEs)

\begin{tabular}{|c|c|c|c|}
\hline Reference & $\begin{array}{l}\text { Interventions and } \\
\text { Sample Size }\end{array}$ & $\begin{array}{l}\text { Adverse Events in the } \\
\text { Intervention Group }\end{array}$ & $\begin{array}{l}\text { Adverse Events } \\
\text { in the Placebo group }\end{array}$ \\
\hline \multicolumn{4}{|c|}{ Pemphigus Vulgaris \& Pemphigus Foliaceus } \\
\hline $\begin{array}{l}\text { Fiorentino et } \\
\text { al. (2011) }\end{array}$ & $\begin{array}{l}\text { Group 1: } \\
\text { IV } 50 \mathrm{mg} \text { etanercept }(n=6) \\
\text { Group 2: } \\
\text { Saline }(n=2)\end{array}$ & $\begin{array}{l}1 \text { hip fracture } \\
1 \text { inj. site reaction } \\
1 \text { ecchymosis and numbness at injection site } \\
1 \text { pemphigus vulgaris flare at week two } \\
1 \text { superficial skin infection }\end{array}$ & $\begin{array}{c}1 \text { headache } \\
2 \text { cases of inj. site reaction }\end{array}$ \\
\hline $\begin{array}{l}\text { Hall et al. } \\
(2015)\end{array}$ & $\begin{array}{l}\text { Group 1: } \\
\text { IV prednisone variable dosage }+ \\
\text { Infliximab }(5 \mathrm{mg} / \mathrm{kg})(\mathrm{n}=10) \\
\text { Group 2: } \\
\text { Prednisone + placebo }(\mathrm{n}=10)\end{array}$ & $\begin{array}{l}0 \text { AEs }>\text { grade } 3 \text { on or before } 18 \text { weeks } \\
1 \text { Severe adverse event grade } 3\end{array}$ & $\begin{array}{l}2 \mathrm{AEs} \text { grade } 3 \\
1 \mathrm{AE} \text { grade } 4 \\
1 \mathrm{AE} \text { grade } 5\end{array}$ \\
\hline $\begin{array}{l}\text { Joly et al. } \\
\text { (2017) }\end{array}$ & $\begin{array}{l}\text { Group 1: } \\
500-1,000 \mathrm{mg} \text { IV rituximab plus } \\
\text { short-term } 0.5-1.0 \mathrm{mg} / \mathrm{kg} \text { daily } \\
\text { prednisone }(\mathrm{n}=46) \\
\text { Group } 2: \\
1.0-1.5 \mathrm{mg} / \mathrm{kg} \text { daily prednisone } \\
\text { alone }(\mathrm{n}=44)\end{array}$ & $\begin{array}{l}\text { (27 SEVERE events grade > } 3 \text { in } 16 \text { patients) } \\
6 \text { diabetes and endocrine disorder (22\%) } \\
3 \text { myopathy (11\%) } \\
5 \text { bone disorders (19\%) }\end{array}$ & $\begin{array}{c}\text { (53 SEVERE events grade > } 3 \text { in } 29 \\
\text { patients) } \\
11 \text { diabetes and endocrine disorder } \\
(21 \%) \\
10 \text { myopathy }(19 \%) \\
5 \text { bone disorders }(9 \%)\end{array}$ \\
\hline \multicolumn{4}{|c|}{ Behçet's Disease } \\
\hline $\begin{array}{l}\text { Melikoglu et } \\
\text { al. (2005) }\end{array}$ & $\begin{array}{l}\text { Group 1: } \\
\text { 25mg of etanercept inj. }(n=10) \\
\text { Group 2: } \\
\text { Placebo }(n=10)\end{array}$ & $\begin{array}{l}1 \text { diarrhea } \\
1 \text { gastrointestinal abdominal pain with bloody } \\
\text { diarrhea with ileocecal ulcer on endoscopy }\end{array}$ & $\begin{array}{l}1 \text { patient had elevated liver enzymes (ALT } \\
144 \mathrm{U} / \mathrm{I}, \mathrm{AST} 71 \mathrm{U} / \mathrm{I} \text { ) and a positive hepati- } \\
\text { tis C virus alongside a negative HCV-RNA, } \\
3 \text { months after the study ended. }\end{array}$ \\
\hline
\end{tabular}

Abbreviations: ALT: alanine aminotransferase; AST: aspartate aminotransferase; inj: injection

outcomes with the addition of rituximab ${ }^{16}$ or infliximab ${ }^{24}$ to prednisone. IgG anti-Dsg1 and Dsg3 antibodies ${ }^{24}$ or total and desmoglein-specific B-lymphocytes ${ }^{16}$ were reduced or disappeared in infliximab plus prednisone or rituximab plus prednisone groups of patients compared to prednisone alone. Based on these results, IV rituximab plus prednisone or IV infliximab plus prednisone may be a superior treatment compared to prednisone alone.

Behçet's Disease: Etanercept was more effective in reducing the number of oral ulcers and achieving complete remission than placebo ${ }^{23}$.

\section{Adverse effects}

Infliximab with prednisone ${ }^{24}$ and rituximab with shortterm prednisone ${ }^{16}$ showed higher safety than prednisone alone in the treatment of pemphigus. The higher safety is likely delivered by the lower dose of prednisone when infliximab or rituximab is added to the treatment. More adverse events were reported when etanercept was utilized for the treatment for pemphigus vs. placebo controls $^{22}$. The number of severe complications was lower, and the overall complications were higher in the etanercept group compared to the placebo in the treatment of Behçet's disease. The active treatment group reported abdominal pain, bloody diarrhea, and an ileocecal ulcer ${ }^{23}$.

\section{Agreements and disagreements with other studies or reviews}

Only RCTs were included in this systematic review.
Five clinical trials were excluded from this review for lack of control group, two were retrospective studies ${ }^{25,26}$, and three were uncontrolled prospective studies ${ }^{27-29}$. Three clinical trials found rituximab to be beneficial in the treatment of recalcitrant pemphigus ${ }^{25,26,28}$ with early treatment within six months of diagnosis being more beneficial ${ }^{26}$. One of the uncontrolled studies with 49 MMP patients (24 receiving rituximab as adjuvant therapy and 25 using conventional therapy), concluded that the addition of rituximab to conventional therapy resulted in faster and more sustained disease control with potentially fewer adverse events ${ }^{29}$. An open-label pilot study with four patients with erosive lichen planus treated via subcutaneous efalizumab showed that two patients experienced serious adverse events ${ }^{27}$. One patient experienced urticaria and a staphylococcal abscess of an artificial hip joint. The second patient had drug-induced subacute cutaneous lupus ${ }^{27}$.

The findings of this systematic review are in agreement with other reviews; that biologic agents offer either an alternative treatment to or adjuvant treatment with glucocorticoids; however, not without risks and significant adverse effects ${ }^{30,31}$. A recent systematic review also identified favorable results when administering rituximab for treating pemphigus ${ }^{32}$. Two reviews concluded that rituximab and a short course of corticosteroids are more effective and safer than standard corticosteroids treatment, leading to its approval as first-line therapy in pemphigus by the FDA in $2018^{33,34}$. According to one review ${ }^{35}$, and a 
systematic review ${ }^{36}$, MMP is less responsive to rituximab than pemphigus. Further studies are needed.

Only one RCT with etanercept has shown beneficial results for Behçet's disease (included in this review ${ }^{23}$ ) with few adverse events ${ }^{37}$. Infliximab and adalimumab are increasingly used for various refractory Behçet's syndrome manifestations despite the lack of controlled studies, according to one review ${ }^{38}$.

\section{Analysis of the influence of risk of bias on the results: Quality of the Evidence}

The overall quality of the evidence (according to the GRADE system) was very low due to the risk of bias (which was high in all studies), a small number of randomized controlled trials for each outcome $(n=1)$, a small sample size (less than 400 total number of participants), heterogeneity of the outcomes reported and quality of study designs. While three DBRCT were included in this review ${ }^{22-24}$, one included study ${ }^{16}$ was an open-label randomized trial. Additionally, one trial was a pilot study ${ }^{22}$. Further randomized controlled trials of a larger scale are needed to improve the quality of the data.

\section{Implications for research and clinical practice}

Infliximab plus prednisone and rituximab plus prednisone were more effective and safer compared to prednisone alone for the treatment of moderate to severe pemphigus. The reduced prednisone dose may be the contributing factor for the lower side effects achieved with the addition of the biologic agents. Those results make these treatments a viable alternative for refractory cases of pemphigus or cases where higher doses of prednisone are contraindicated. In June 2018, the US Food and Drug Administration approved rituximab for the treatment of adults with moderate to severe pemphigus vulgaris. Both systemic steroids and rituximab are considered first-line treatment ${ }^{39}$. According to the European Dermatology Forum, rituximab is indicated in patients who remain dependent on more than $10 \mathrm{mg}$ prednisolone combined with an immunosuppressive adjuvant ${ }^{40}$. Using biologics, in general, allows for more rapid tapering of systemic steroid doses and a major steroid-sparing ${ }^{39}$. Research related to maintenance infusions of rituximab or infliximab is indicated as infusion may keep B-lymphocytes and IgG anti-Dsg1 and Dsg3 antibodies at the desired levels and reducing relapse. Similarly, etanercept is showing a reduction of relapses in refractory Behçet's disease ${ }^{41}$.

Infliximab binds to soluble and transmembrane forms of TNF- $\alpha$, which prevents TNF- $\alpha$ from interacting with its receptors. The therapeutic role of infliximab is an anti-inflammatory role by downregulation of local and systemic pro-inflammatory cytokines (i.e., IL-1, IL-6), and reduction of lymphocyte and leukocyte migration to sites of inflammation ${ }^{17}$. On the other hand, desmoglein antigens, which play an essential role in the pathogenesis of pemphigus, are produced by plasma cells developed from autoreactive B-cells; Rituximab may act by binding to the CD20 cell surface receptor of B-cells and destroy them ${ }^{18}$. Thus the therapeutic role of rituximab is suppressing the autoimmune reaction against the skin or/and mucosa. The long term safety, cost, and efficacy of the infusions need to be further investigated.

Etanercept, which is a receptor fusion protein that inhibits TNF- $\alpha$, was an effective treatment in reducing the number of oral ulcers and achieving complete remission in Behçet's disease in one study compared to placebo ${ }^{23}$. However, the effect of etanercept on women with Behçet's needs to be investigated, as the study did not include women. Etanercept was more effective in the treatment of oral ulcers than ulcers in other body locations in patients with Behçet's disease. Although the effectiveness of etanercept for pemphigus patients is heterogeneous, it has a favorable outcome with Behçet's patients ${ }^{19}$. Why etanercept was effective for Behçet's while ineffective for pemphigus may be due to the difference in pathogenesis between these conditions and/or inadequate dosing/ administration.

Further research in optimal dosing, selection, and administration of biologic treatments is necessary. This is a relatively new therapy with an unknown cost. Finally, well designed and high-quality studies limited to oral manifestations of these conditions will allow for improved clinical application and usefulness.

In conclusion, this systematic review found the use of biologic agents as an adjunct to prednisone may reduce the amount of required steroid, thus reducing the adverse effects of steroid usage in pemphigus patients. However, more studies are needed to confirm the benefits of biologic agents, considering the heterogeneity of the included research (conditions, interventions, outcomes, comparison groups, and adverse events). Although the addition of biologic agents to prednisone may show promise, the current evidence is inadequate to support the routine administration of biologic medications as first-line therapy for the prevention or treatment of Behçet's disease.

\section{Acknowledgments}

The authors would like to thank Dr. James E. Cade, DDS, Meharry Medical College School of Dentistry for his helpful review of the manuscript. This systematic review was registered with PROSPERO \#CRD42019128312.

\section{Conflict of Interest}

There was no financial support for this review, and the authors have no conflicts of interest to declare. 


\section{Abbreviations}

RCT: Randomized controlled trial; DBRCT: Doubleblinded Randomized Controlled Trial; MSU: monosodium urate; ALT: alanine aminotransferase; AST: aspartate aminotransferase.

\section{References}

1. Jimson $\mathrm{S}$, Balachader $\mathrm{N}$, Anita $\mathrm{N}$, et al. Immunologically mediated oral diseases. J Pharm Bioall Sci. 2015; 7: S209-12. doi:10.4103/09757406.155909

2. Kilic A. Pemphigus: Subtypes, Clinical Features, Diagnosis, and Treatment. Autoimmune Bullous Dis. 2018. doi:10.5772/ intechopen.71712

3. Santoro FA, Stoopler ET, Werth VP. Pemphigus. Dent Clin North Am 2013; 57(4): 597-610. doi:10.1016/j.cden.2013.06.002

4. Nousari HC, Anhalt GJ. Pemphigus and bullous pemphigoid. Lancet 1999; 354(9179): 667-672. doi:10.1016/S0140-6736(99)03007-X

5. Amagai M, Nishikawa T, Nousari HC, et al. Antibodies against desmoglein 3 (pemphigus vulgaris antigen) are present in sera from patients with paraneoplastic pemphigus and cause acantholysis in vivo in neonatal mice. J Clin Invest. 1998; 102(4): 775-782. doi:10.1172/JCI3647

6. Becet $\mathrm{H}$. [Uber rezidivierende, aphthose, dürch ein Virus versachte Geshwure am Munde, am Auge und an den Genitalien]. German. Dermatologische Wochenschrift. 1937; 105: 1152-1163.

7. Sakane T. New perspective on Behcet's disease. Int Rev Immunol. 1997; 14(1): 89-96. doi:10.3109/08830189709116847

8. Torchia D, Caproni M, Fabbri P. Linear IgA disease and desquamative gingivitis: Time for inclusion in mucous membrane pemphigoid. Oral Dis. 2008; 14(8): 768-769. doi:10.1111/j.1601-0825.2008.01485.x

9. Hello M, Barbarot S, Bastuji-Garin S, et al. Use of thalidomide for severe recurrent aphthous stomatitis: A multicenter cohort analysis. Medicine (Baltimore). 2010; 89(3): 176-182. doi:10.1097/ MD.0b013e3181dfca14

10. Carbone M, Arduino PG, Carrozzo M, et al. Topical clobetasol in the treatment of atrophic-erosive oral lichen planus: A randomized controlled trial to compare two preparations with different concentrations. J Oral Pathol Med. 2009; 38(2): 227-233. doi:10.1111/ j.1600-0714.2008.00688.x

11. Chams-Davatchi C, Esmaili N, Daneshpazhooh M, et al. Randomized controlled open-label trial of four treatment regimens for pemphigus vulgaris. J Am Acad Dermatol. 2007; 57(4): 622-628. doi:10.1016/j. jaad.2007.05.024

12. Chan LS, Ahmed AR, Anhalt GJ, et al. The First International Consensus on Mucous Membrane Pemphigoid. Arch Dermatol. 2002; 138(3). doi:10.1001/archderm.138.3.370

13. Fani MM, Ebrahimi H, Pourshahidi S, et al. Comparing the Effect of Phenytoin Syrup and Triamcinolone Acetonide Ointment on Aphthous Ulcers in Patients with Behcet's Syndrome. Iran Red Crescent Med J. 2012; 14(2): 75-78.

14. Schäcke H, Döcke WD, Asadullah K. Mechanisms involved in the side effects of glucocorticoids. Pharmacol Ther. 2002; 96(1): 23-43. doi:10.1016/S0163-7258(02)00297-8

15. Almugairen N, Hospital V, Bedane C, et al. Assessment of the rate of long-term complete remission off therapy in patients with pemphigus treated with different regimens including medium- and highdose corticosteroids. J Am Acad Dermatol. 2013; 69(4): 583-588. doi:10.1016/j.jaad.2013.05.016

16. Joly P, Maho-Vaillant M, Prost-Squarcioni C, et al. First-line rituximab combined with short-term prednisone versus prednisone alone for the treatment of pemphigus (Ritux 3): a prospective, multicentre, parallel-group, open-label randomised trial. Lancet. 2017; 389(10083): 2031-2040. doi:10.1016/S0140-6736(17)30070-3

17. Knight DM, Trinh $\mathrm{H}$, Le J, et al. Construction and initial characterization of a mouse-human chimeric anti-TNF antibody. Mol Immunol. 1993; 30(16): 1443-1453. doi:10.1016/0161-5890(93)90106-L

18. Perosa F, Favoino E, Caragnano MA, et al. CD20: A target antigen for immunotherapy of autoimmune diseases. Autoimmun Rev. 2005; 4(8): 526-531. doi:10.1016/j.autrev.2005.04.004

19. Marotte H, Cimaz R. Etanercept - TNF receptor and IgG1 Fc fusion protein: is it different from other TNF blockers? Expert Opin Biol Ther. 2014; 14(5): 569-572. doi:10.1517/14712598.2014.896334

20. Moher D, Liberati A, Tetzlaff J, et al. Preferred reporting items for systematic reviews and meta-analyses: the PRISMA statement. PLoS Med. 2009; 6(7): e1000097. doi:10.1371/journal.pmed.1000097

21. Higgins J, Green S (editors). Cochrane Handbook for Systematic Reviews of Interventions Version 5.1.0 [Updated March 2011].; 2011. www.cochrane-handbook.org.

22. Fiorentino DF, Garcia MS, Rehmus W, et al. A Pilot Study of Etanercept Treatment for Pemphigus Vulgaris. Arch Dermatol. 2010; 147(1): 117. doi:10.1001/archdermatol.2010.409

23. Melikoglu M, Fresko I, Mat C, et al. Short-term trial of etanercept in Behcet's disease: A double blind, placebo controlled study. J Rheumatol. 2005; 32(1): 98-105. http://www.embase.com/search/ results?subaction=viewrecord $\&$ from=export\&id=L40092599.

24. Hall RP 3rd, Fairley J, Woodley D, et al. A multicentre randomized trial of the treatment of patients with pemphigus vulgaris with infliximab and prednisone compared with prednisone alone. Br J Dermatol. 2015; 172(3): 760-768. doi:10.1111/bjd.13350

25. Arduino PG, Broccoletti R, Carbone M, et al. Long-term evaluation of pemphigus vulgaris: A retrospective consideration of 98 patients treated in an oral medicine unit in north-west Italy. J Oral Pathol Med. 2019; 48(5): 406-412. doi:10.1111/jop.12847

26. Balighi K, Daneshpazhooh M, Akbari Z, et al. Comparing the shortterm therapeutic effects and safety profiles of rituximab therapy in pemphigus vulgaris patients either early treated or later than six months. J Dermatolog Treat. 2019; 30(4): 346-349. doi:10.1080/09 546634.2018.1509049

27. Heffernan MP, Smith DI, Bentley D, et al. A single-center, open-label, prospective pilot study of subcutaneous efalizumab for oral erosive lichen planus. J Drugs Dermatol. 2007; 6(3): 310-314.

28. Kanwar AJ, Vinay K, Sawatkar GU, et al. Clinical and immunological outcomes of high- and low-dose rituximab treatments in patients with pemphigus: a randomized, comparative, observer-blinded study. Br J Dermatol. 2014; 170(6): 1341-1349. doi:10.1111/bjd.12972

29. Maley A, Warren M, Haberman I, et al. Rituximab combined with conventional therapy versus conventional therapy alone for the treatment of mucous membrane pemphigoid (MMP). J Am Acad Dermatol. 2016; 74(5): 835-840. doi:10.1016/j.jaad.2016.01.020

30. O'Neill ID. Off-label use of biologicals in the management of inflammatory oral mucosal disease. J oral Pathol Med Off Publ Int Assoc Oral Pathol Am Acad Oral Pathol. 2008; 37(10): 575-581. doi:10.1111/j.1600-0714.2008.00693.x

31. O'Neill ID, Scully CIDOCS. Biologics in oral medicine: Ulcerative disorders. Oral Dis. 2013; 19(1): 37-45. doi:10.1111/j.16010825.2012.01931.x

32. Kaegi C, Wuest B, Schreiner J, et al. Systematic Review of Safety and Efficacy of Rituximab in Treating Immune-Mediated Disorders. Front Immunol. 2019; 10(September): 1-18. doi:10.3389/ fimmu.2019.01990 
33. Bilgic A, Murrell DF. What is novel in the clinical management of pemphigus. Expert Rev Clin Pharmacol. 2019; 12(10): 973-980. doi:1 $0.1080 / 17512433.2019 .1670059$

34. Didona D, Maglie R, Eming R, et al. Pemphigus: Current and future therapeutic strategies. Front Immunol. 2019; 10(June): 1-28. doi:10.3389/fimmu.2019.01418

35. Buonavoglia A, Leone P, Dammacco $\mathrm{R}$, et al. Pemphigus and mucous membrane pemphigoid: An update from diagnosis to therapy. Autoimmun Rev. 2019; 18(4): 349-358. doi:10.1016/j. autrev.2019.02.005

36. Mays JW, Carey BP, Posey R, et al. World Workshop of Oral Medicine VII: A systematic review of immunobiologic therapy for oral manifestations of pemphigoid and pemphigus. Oral Dis. 2019; 25(S1) 111-121. doi:10.1111/odi.13083

37. Leccese P, Ozguler Y, Christensen R, et al. Management of skin, mucosa and joint involvement of Behçet's syndrome: A systematic review for update of the EULAR recommendations for the management of
Behçet's syndrome. Semin Arthritis Rheum. 2019; 48(4): 752-762. doi:10.1016/j.semarthrit.2018.05.008

38. Esatoglu SN, Hatemi G. Update on the treatment of Behçet's syndrome. Intern Emerg Med. 2019; 14(5): 661-675. doi:10.1007/s11739-01902035-1

39. Murrell DF, Peña S, Joly $\mathrm{P}$, et al. Diagnosis and management of pemphigus: Recommendations of an international panel of experts. J Am Acad Dermatol. 2020; 82(3): 575-585.e1. doi:10.1016/j. jaad.2018.02.021

40. Hertl M, Jedlickova H, Karpati S, et al. Pemphigus. S2 Guideline for diagnosis and treatment - Guided by the European Dermatology Forum (EDF) in cooperation with the European Academy of Dermatology and Venereology (EADV). J Eur Acad Dermatology Venereol. 2015; 29(3): 405-414. doi:10.1111/jdv.12772

41. Ma D, Zhang CJ, Wang RP, et al. Etanercept in the Treatment of Intestinal Behcet's Disease. Cell Biochem Biophys. 2014; 69(3): 735739. doi:10.1007/s12013-014-9860-4 